\title{
Secular Trends of Sizes at Birth in Russian Infants Born between 1987 and 2002
}

\author{
Anna Tretyak $^{1)}$, Elena Godina ${ }^{2)}$ and Ludmila Zadorozhnaya ${ }^{2)}$ \\ 1) Department of Anthropology, Biology Faculty, Moscow State University, Moscow, Russia \\ 2) Institute and Museum of Anthropology, Moscow State University, Moscow, Russia
}

\begin{abstract}
Secular changes in the body dimensions of newborns from three different geographical localities are compared. Anthropometrical data of infants born in 1987 and in 2002 as a result of singleton full-term non-pathological postpartum were collected from medical records of children's out-patient clinics in three geographical localities: two big cities-Moscow and Saratov-and the town of Khvalynsk (Saratov region). The total number of newborns used in the analysis was 1,174. Body length and weight at birth from 1987 to 2002 increased in Moscow and Saratov, while in Khvalynsk there was a significant decrease of body length for boys. There is also a trend towards decrease of body weight in Khvalynsk boys and girls. It may be assumed that the changes in body sizes of newborns may be connected with socio-economic changes. J Physiol Anthropol Appl Human Sci 24(4): 403-406, 2005 http://www.jstage.jst.go.jp/browse/jpa

[DOI: 10.2114/jpa.24.403]
\end{abstract}

Keywords: newborns, weight, body length, secular trend, socio-economic changes

\section{Introduction}

The processes of growth and development are known to be genetically programmed with an orderly pattern of changes developing under the influence of internal and external factors. There are several environmental factors influencing the amount and rate of physical growth during the life cycle. Of these factors, socioeconomic status, nutrition, and chronic diseases are essential for retarding or accelerating the hereditary growth potential of the individual child (Mlyńska, 2002). These factors also influence the course of intrauterine growth, which is reflected in bigger or smaller sizes of newborns (Nikityuk et al., 1990).

As was shown in a number of studies, low birth weight was caused by unfavorable socio-economic conditions (Letamo and Majelantle, 2001; Mohsin et al., 2003; Oishi et al., 2004). The fact of morphological differences between groups of children living in different ecological zones, in urban and rural areas was also proved by numerous researchers. Pawson et al. (2001) revealed differences in body length of children born by mothers who lived under different socio-economic conditions. Ulijaszek (2001) showed the trend towards body weight increase in Papua New Guinea.

The process that results in a change in the mean size or shape of a population from one generation to the next is known as a secular trend in growth. Anthropologists stated that for the last 150 years the body sizes of children and adults were generally increasing, although there were periods of relative decrease caused by social catastrophes such as wars and economic crisis.

Secular trend is a phenomenon typical for many world countries and for different stages of ontogenesis. Secular changes of body dimensions in adults and children are welldocumented. Similar changes in newborns are not so well studied.

Secular changes in body dimensions of newborns were registered in the former Soviet Union (Nikityuk et al., 1990; Vlastovsky, 1976). In Moscow, the changes of body length, weight and body circumferences at birth have been registered since the end of the 19th century. The changes were multidirectional: the periods of increase and decrease followed in a row. It should be noted that the usual differences between sexes remained: all body dimensions in boys were greater than in girls (Nikityuk et al., 1990).

At present in many developed countries there is a stabilization of the tempos of growth (Cole, 2003). The same trend is typical for Moscow schoolchildren. It was shown in several papers that secular changes of Moscow children from 7 to 17 in the last decades of the 20th century show a tendency towards linearity, stabilization of growth in length, and later ages of sexual maturation (see e.g., Godina and Yampolskaya, 2004). However, the data on changes at birth are practically non-existent. That is why the main purpose of the present paper was to follow the changes of newborns for the last 15 years and to see if they are connected with the drastic socioeconomic transformations that happened in Russian society during this period of time. 


\section{Materials and Methods}

Anthropometric data of children born in 1987 in 2002 were collected in three localities of the Russian Federation with different ecological, social and economic conditions. Moscow, the capital of Russia, is a highly urbanized city with a population, according to different estimations, of 10-15 million people. Saratov (in the Volga River area) is also an industrial city, a regional center with a population of about $1,000,000$. The third place under investigation was the town of Khvalynsk (Saratov region, Volga River area) with a population of 15,000 people and a low level of urbanization and industrialization.

The data on length and weight of infants measured at birth in the maternity hospitals were collected from the medical records of children's out-patient clinics by one of the authors $(A T)$. All infants were born as a result of singleton full-term non-pathological postpartum with a birth weight exceeding $2.5 \mathrm{~kg}$.

The total number of extracted data was 1,174 . The number of newborns from each place is shown in Table 1. It should be noted that in Khvalynsk practically all children born in these years were taken into account.

Statistical analysis was conducted using Statistica 6.0

Table 2 The percentage of first-, second-, third-or-above-born infants

\begin{tabular}{|c|c|c|c|c|c|c|c|c|c|c|c|c|}
\hline \multirow{3}{*}{$\begin{array}{l}\text { Year } \\
\text { City }\end{array}$} & \multicolumn{6}{|c|}{1987} & \multicolumn{6}{|c|}{2002} \\
\hline & \multicolumn{2}{|c|}{ Moscow } & \multicolumn{2}{|c|}{ Saratov } & \multicolumn{2}{|c|}{ Khvalynsk } & \multicolumn{2}{|c|}{ Moscow } & \multicolumn{2}{|c|}{ Saratov } & \multicolumn{2}{|c|}{ Khvalynsk } \\
\hline & No. & $\%$ & No. & $\%$ & No. & $\%$ & No. & $\%$ & No. & $\%$ & No. & $\%$ \\
\hline First & 68 & 56.7 & 131 & 60.7 & 46 & 61.3 & 137 & 66.5 & 143 & 66.2 & 107 & 58.8 \\
\hline Second & 43 & 35.8 & 72 & 33.3 & 23 & 30.7 & 59 & 25.6 & 58 & 26.9 & 63 & 34.6 \\
\hline Third or above & 9 & 7.5 & 13 & 6.0 & 6 & 8.0 & 10 & 4.0 & 15 & 6.9 & 12 & 6.6 \\
\hline Unknown & 3 & - & 17 & - & 104 & - & 2 & - & 4 & - & 29 & - \\
\hline
\end{tabular}

\section{Boys}

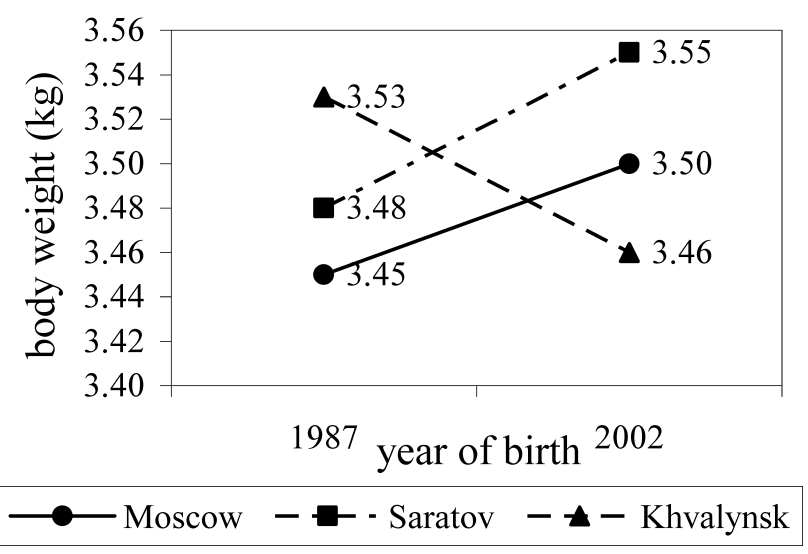

Fig. 1 Comparison of weight among boys. software. The significance of differences between groups was assessed with ANOVA.

\section{Results}

In 1987 the mean age of mothers was 26.4 years in all three cities. In 2002 it increased in Moscow and Saratov to 26.7 years, and in Khvalynsk decreased to 25.0.

Table 2 shows the changes in proportion of first-, secondand third-or-above-born infants in the three places during the 15 years. In all groups more than $50 \%$ of infants were firstborn, and about 30\% second-born. In Moscow and Saratov the percentage of first-borns has increased over the 15 years, while in Khvalynsk it has decreased.

Figs. 1-4 demonstrate the changes in body dimensions of

Table 1 Number of children in different groups

\begin{tabular}{c|c|c|c|c|c|c}
\hline \multirow{2}{*}{ City } & \multicolumn{2}{|c|}{ Moscow } & \multicolumn{2}{c|}{ Saratov } & \multicolumn{2}{c}{ Khvalynsk } \\
\hline Year & boys & girls & boys & girls & boys & girls \\
\hline 1987 & 61 & 62 & 111 & 122 & 74 & 105 \\
\hline 2002 & 104 & 104 & 110 & 110 & 107 & 104 \\
\hline
\end{tabular}




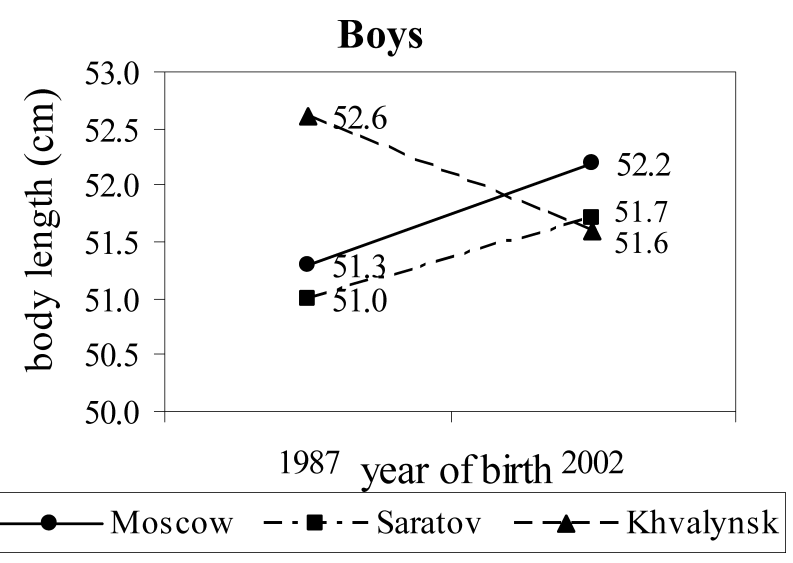

Fig. 3 Comparison of body length among boys.

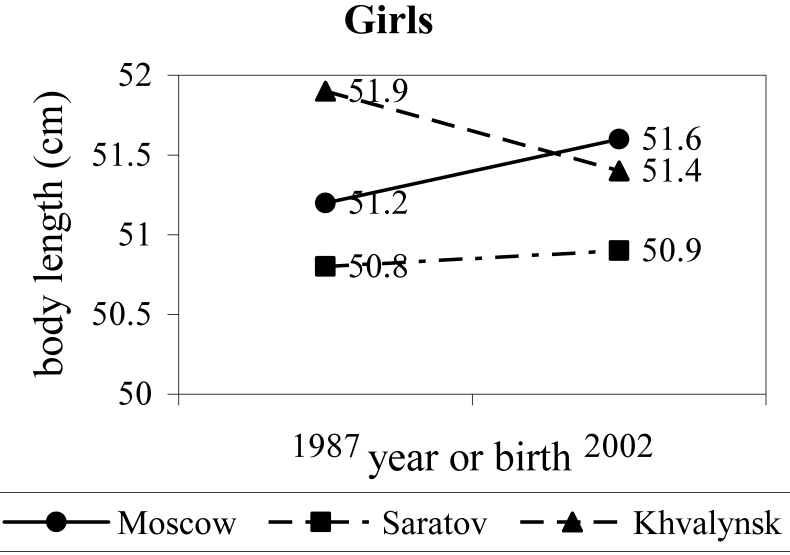

Fig. 4 Comparison of body length among girls.

Table 3 Comparison of newborn sizes between cities by groups (ANOVA), p level

\begin{tabular}{c|c|c|c|c|c|c|c}
\hline \multicolumn{2}{c|}{ City } & \multicolumn{2}{c|}{ Moscow vs. Saratov } & \multicolumn{2}{c}{ Moscow vs. Khvalynsk } & \multicolumn{2}{c}{ Saratov vs. Khvalynsk } \\
\hline \multirow{2}{*}{ Year } & 1987 & 2002 & 1987 & 2002 & 1987 & 0.435 \\
\hline \multirow{3}{*}{ Boys } & Weight & 0.738 & 0.439 & 0.318 & 0.473 & 0.137 \\
\cline { 2 - 9 } & Length & 0.220 & 0.078 & 0.009 & 0.038 & 0.000 & 0.785 \\
\hline \multirow{3}{*}{ Girls } & Weight & 0.955 & 0.439 & 0.856 & 0.473 & 0.879 & 0.137 \\
\cline { 2 - 9 } & Length & 0.174 & 0.078 & 0.149 & 0.038 & 0.002 & 0.785 \\
\hline
\end{tabular}

newborns.

In 1987, there were few differences in body weight between male infants born in Moscow, Saratov and Khvalynsk. In body length, newborn boys from Khvalynsk were significantly larger than those from Saratov and Moscow (Table 3). The same patterns can be seen for newborn girls.

In 2002, newborn boys from the three localities studied also did not differ in body weight, but in body length the Khvalynsk male infants were significantly shorter than those in Moscow. The girls from the three localities also did not show significant differences in weight, and girls from Moscow had the largest body length at birth with significant differences when compared to newborn girls from Khvalynsk (Table 3).

Weight and length at birth in infants of both sexes increased in Moscow and Saratov between 1987 and 2002, for boys significantly (Table 4). In Khvalynsk, the length of newborn boys shows a significant decrease. There is also a tendency towards a decrease of body weight. For newborn girls of Khvalynsk the differences are non-significant but there is also a tendency towards a decrease of body length.

\section{Discussion}

Secular changes of body size at birth are not as well followed as changes in children of older ages. In Russia there are some data of changes in body dimensions of infants since the end of the 19th century (Nikityuk, 1990). For the last 100+
Table 4 Comparison of newborn sizes between 1987 and 2002 (ANOVA), p level

\begin{tabular}{c|c|c|c|c}
\hline \multirow{3}{*}{ Boys } & City & Moscow & Saratov & Khvalynsk \\
\cline { 2 - 5 } & Weight & 0.498 & 0.247 & 0.278 \\
\cline { 2 - 5 } & Length & 0.006 & 0.009 & 0.043 \\
\hline \multirow{3}{*}{ Girls } & Weight & 0.196 & 0.692 & 0.913 \\
\cline { 2 - 5 } & Length & 0.168 & 0.396 & 0.194 \\
\hline
\end{tabular}

years there were periods of increase and decrease of size at birth, which could be explained by changes in the socioeconomic situation. Thus, a decrease was noted during the 2nd World War, and a maximum noted in the mid-1980s (Nikityuk, 1990). It was also the time of maximal birth rates (13.8).

The late 1980s and early 1990s witnessed the start of a period of drastic political, economic and social changes in Russia. The process is ongoing, with different tempos and consequences in big and small cities. While in Moscow and Saratov, which are big industrial cities, there were some beneficial changes; in the small town of Khvalynsk the changes were connected with a higher degree of unemployment, paternal mortality, and lower standards of living (Godina et al., in press). 
Newborn boys from Moscow and Saratov equally increased in body size over the 15 years - approximately by $1 \mathrm{~cm}$ in height and 50-70 $\mathrm{g}$ in weight (Figs. 1, 3). At the same time the differences between the newborns from the two urban groups remained practically unchanged (Table 4).

Khvalynsk shows a different trend. This little provincial town has gone through unfavorable socio-economic changes. Hence, the growth of newborn boys shows some signs of retardation: their body weight and length decreased by $1 \mathrm{~cm}$ and $70 \mathrm{~g}$ (the same amount as the gains in those dimensions in Moscow and Saratov).

The girls were less affected by the changes: in Moscow their length increased by $0.4 \mathrm{~cm}$, in Saratov remained the same, and in Khvalynsk decreased by $0.5 \mathrm{~cm}$ (Fig. 4). Weight at birth increased in Moscow by $90 \mathrm{~g}$ but did not change in Saratov and Khvalynsk (Fig. 2).

Of course we realize that the small observation number somewhat limits the validity of our conclusions. However, the main result about negative secular changes in the body length of Khvalynsk newborns is supported by another study, by Kakorina and Tcheplyagina (1998), who showed that for the 15 years of "perestroika" there was a decrease in skeletal growth of schoolchildren from Khvalynsk, both for boys and girls.

Thus, the changes in body dimensions at birth seem to be closely connected with political, social and economic changes in society (Oishi et al., 2004). Further studies are needed to follow the degree and directions of those changes in future.

Acknowledgement The authors are grateful to the staff of children's out-patient clinics in Khvalynsk, Saratov and Moscow for permission to use medical records.

\section{References}

Cole TJ (2003) The secular trend in human physical growth: a biological view. Economics Hum Biol 1: 161-168

Godina E, Yampolskaya Y (2004) Recent secular growth changes in Moscow schoolchildren. Anthrop Kozl 45: 51-57

Godina EZ, Khomyakova IA, Zadorozhnaya LV, Purundzhan AL, Stepanova AV (2005) Natural and socio-economic factors influencing growth: The case of children from the
Saratov region. In Baranov AA, Tcheplyagina LA eds. Physiology of the growing child. [In Russian] (in press)

Kakorina EP, Scheplyagina LA (1998) Physical development of schoolchildren from 6 to 15 in the Khvalynsk rayon of the Saratov region. In Materials on physical development of children and adolescents in urban and rural areas of the Russian Federation 5. Moscow, 100-101 [In Russian]

Letamo G, Majelantle RG (2001) Factors influencing low birth weight and prematurity in Botswana. J Biosoc Sci 33: 391403

Mlyńska D (2002) Physical growth in early childhood in relation to environmental factors. Variability and Evolution 10: 91-93

Mohsin M, Wong F, Bauman A, Bai J (2003) Maternal and neonatal factors influencing premature birth and low birth weight in Australia. J Biosoc Sci 35: 161-174

Nikityuk BA, Musagalieva GM, Savchenko KA (1990) Acceleration of children's development and its consequences. Alma-Ata, Kazakhstan, 7-30 [In Russian]

Oishi K, Honda S, Takamura N, Kusano Y, Abe Y, Moji K, Takemoto T, Tahara Y, Aoyagi K (2004) Secular trends of sizes at birth in Japanese healthy infants born between 1962 and 1988. J Physiol Antropol Appl Human Sci 23: 155-161

Pawson IG, Huicho L, Muro M, Pacheco A (2001) Growth of children in two economically diverse Peruvian high-altitude communities. Am J Hum Biol 13: 323-340

Ulijaszek SJ (2001) Secular trend in birthweight among the Purari delta population, Papua New Guinea. Ann Hum Biol 28: 246-255

Vlastovsky VG (1976) Acceleration of children's growth and development. Moscow State University, Moscow, 1-150 [In Russian]

Received: March 25, 2005

Accepted: March 31, 2005

Correspondence to: Anna Tretyak, Department of Anthropology, Biology Faculty, Moscow State University, Vorobyovi Gori, Moscow 119899, Russia

Phone: +7-095-939-2746

Fax: +7-095-939-2746

e-mail: ania_83@mail.ru 